goes everywhere without fear, and I would say, Why does a city allow such places to exist where it would not be safe for a woman to enter?

Our fellow-men live there and will do so until a reform it brought about, and as a large amount of reform work is inaugurated by women, this field is legitimately woman's sphere.

\title{
NURSING THE HAIR
}

A TrRed trained nurse had reached the age at which it was no longer possible for her to give to her work the enthusiasm she considered necessary. Her years of labor had brought their reward, and she was able to pause long enough to decide what her work in the future should be.

It was plain that her own profession was too exacting. It was also plain that her new vocation should be in the line of her old employment, as it was too late in life for her to begin anything new. She consulted with her colleagues and with her friends among the physicians. None of them was able to suggest just the employment that suited her case.

The solution of the problem came finally, as most satisfactory things do, through her own inspiration. Then she went to a physician who had become famous in the specialty she proposed to follow and made this proposition to him:

"You're a specialist in the treatment of the hair and have succeeded in acquiring a reputation that brings patients to you from all over the country," she said. "Now, I want to become a nurse for the hair, just as you are a physician for it.

"I know that you always recommend certain exercises to your patients which are to be done by their maids or by some professional masseuse. Now, many of your patients have no maids and would rather be treated by a trained nurse who knows something of hygiene than by a masseuse. I want to be that sort of nurse. Is there any opportunity for a woman to succeed in work of that kind ?'

The hair specialist, who happened to be bald himself, met her suggestion with greater enthusiasm than she had hoped for. He was certain that sufficient employment could be found for her.

So the woman gave up the work of regular nursing and set out to devote herself exclusively to the hair. Her first patients came from the physician. The number increased rapidly and she soon had plenty to do. She was able to give more satisfaction to the patients than they had ever before enjoyed because she had all the skill that came from 
experience in nursing. They all felt that treatment aided by her ministrations was more effective, and there was scarcely a patient of this hair specialist who did not want her. Other doctors who treat the hair heard of her, and she was called in by their patients as well.

"I've as much as I can do," she said the other day, " and I earn almost as much as I did formerly with none of the trouble of night work and the long confining hours of the sick-room. I am not alarmed about the work in the future, because I believe that the treatment of the hair is a thing that will continue and, moreover, increase from year to year.

"My visits at a house rarely last longer than a half or threequarters of an hour. I have the exercise of going from place to place, and, of course, no woman wants her hair treated at night. So I have fortunately found my new occupation profitable, although I could never have attempted it without the interest of the doctor who first started me in the work."

\section{COCAIN DRUNKENNESS}

AN order has been issued to the police of New Orleans by Chief of Police Caster to arrest all persons dealing illegally in cocain or suffering from cocain drunkenness. The order said: "The constant use of cocain has assumed large and serious proportions, and is daily increasing to such an extent as to be a menace to public health. You are directed to notify the force under your command to use extreme diligence in enforcing the city ordinance against the use of cocain and to make arrests. This menace is general throughout the city. This order must be strictly adhered to, and you will make written reports to this office of each offender arrested and from whom the drug was purchased, whether from a druggist or pedler."

\section{FIRST WOMAN PHARMACIST IN RUSSIA}

Madame Lessievskaja, who has received the degree of Master of Pharmacy, has also secured the necessary authorization from the government to open a pharmacy in Moscow. She is the first woman in Russia to be accorded this privilege. In connection with her establishment there will be a chemical laboratory and a school for women pharmacists. 